\title{
Assessment of the Concentration of Inorganic Chemical Elements in the Pollution Status of Water Boreholes in Awka- Anambra Sedimentary Basin, Se, Nigeria
}

\author{
Onunkwo A. A. \\ Department of Geology, Federal University of Technology, Owerri \\ Onyekuru S. O. \\ Department of Geology, Federal University of Technology, Owerri \\ Opara K. D. \\ Department of Geology, Federal University of Technology, Owerri
}

Uche F. Ikechukwu

Department of Building, Imo State University, Owerri

Received: January 13, 2017 Accepted: March 27, 2017

doi:10.5296/emsd.v6i1.11030 URL: https://doi.org/10.5296/emsd.v6i1.11030

\begin{abstract}
Since Awka town was made the capital of Anambra State, population growth, innumerable industries and other new land uses have been on the increase. There is the fear that inorganic geochemical elements may have contaminated the groundwater making it unfit for consumption. This research is thus intended to estimate the magnitude to which borehole waters and by extension the groundwater system in the area have been contaminated. Six borehole water samples were collected and analysed for inorganic geochemical elements. The parameters analysed were colour, acidity, $\mathrm{pH}$, conductivity, total dissolved and suspended solids (TDS and TSS). Others are nitrate $\left(\mathrm{NO}_{3}\right)$, chloride $\left(\mathrm{Cl}^{-}\right)$, sulphate $\left(\mathrm{SO}_{4}{ }^{2-}\right)$, phosphate $\left(\mathrm{PO}_{4}{ }^{3}\right)$ copper $\left(\mathrm{Cu}^{2+}\right)$, lead $\left(\mathrm{Pb}^{2+}\right)$, cadmium $\left(\mathrm{Cd}^{2+}\right)$, zinc $\left(\mathrm{Zn}^{2+}\right)$, iron $\left(\mathrm{Fe}^{2+}\right)$, total hardness (calcium hardness and magnesium hardness) (total hardness) and alkalinity. The analyses were conducted with appropriate geochemical equipment. It was discovered that other anions
\end{abstract}




\section{Macrothink}

apart from phosphate are within the concentrations recommended for safe drinking water. The concentration of the cations is in the following order: $\mathrm{Cl}>\mathrm{HCO}_{3}>\mathrm{SO}_{4}>\mathrm{NO}_{3}$, and that for anions is $\mathrm{Mg}>\mathrm{Ca}>\mathrm{K}>\mathrm{Na}$, thus making the water in the area potentially magnesium chloride water. Iron and lead are the only heavy metals whose concentrations are high. Lead is toxic but iron only stains and causes intestinal disturbance.

Keywords: Inorganic, Geochemical, Elements, Land use, Anions, Cations, Pollution, Groundwater

\section{Introduction}

The creation of Anambra State with Awka as its capital has engendered high population growth rate, innumerable industries and other new land users have continued to generate wastes that are inappropriately disposed. The fear that groundwater in the area may have been contaminated and unfit for consumption is therefore certain and a cause for concern. The aim of the study is therefore to determine the extent to which inorganic chemical constituents in the study area has polluted the groundwater system as an appropriate measure for pollution control and sustainable development.

Awka area is located between Latitudes $6^{\circ} 00^{1}$ and $6^{\circ} 15^{1} \mathrm{~N}$ and Longitudes $7^{\circ} 01^{1}$ and $7^{\circ} 11^{1} \mathrm{E}$, Figure 1.

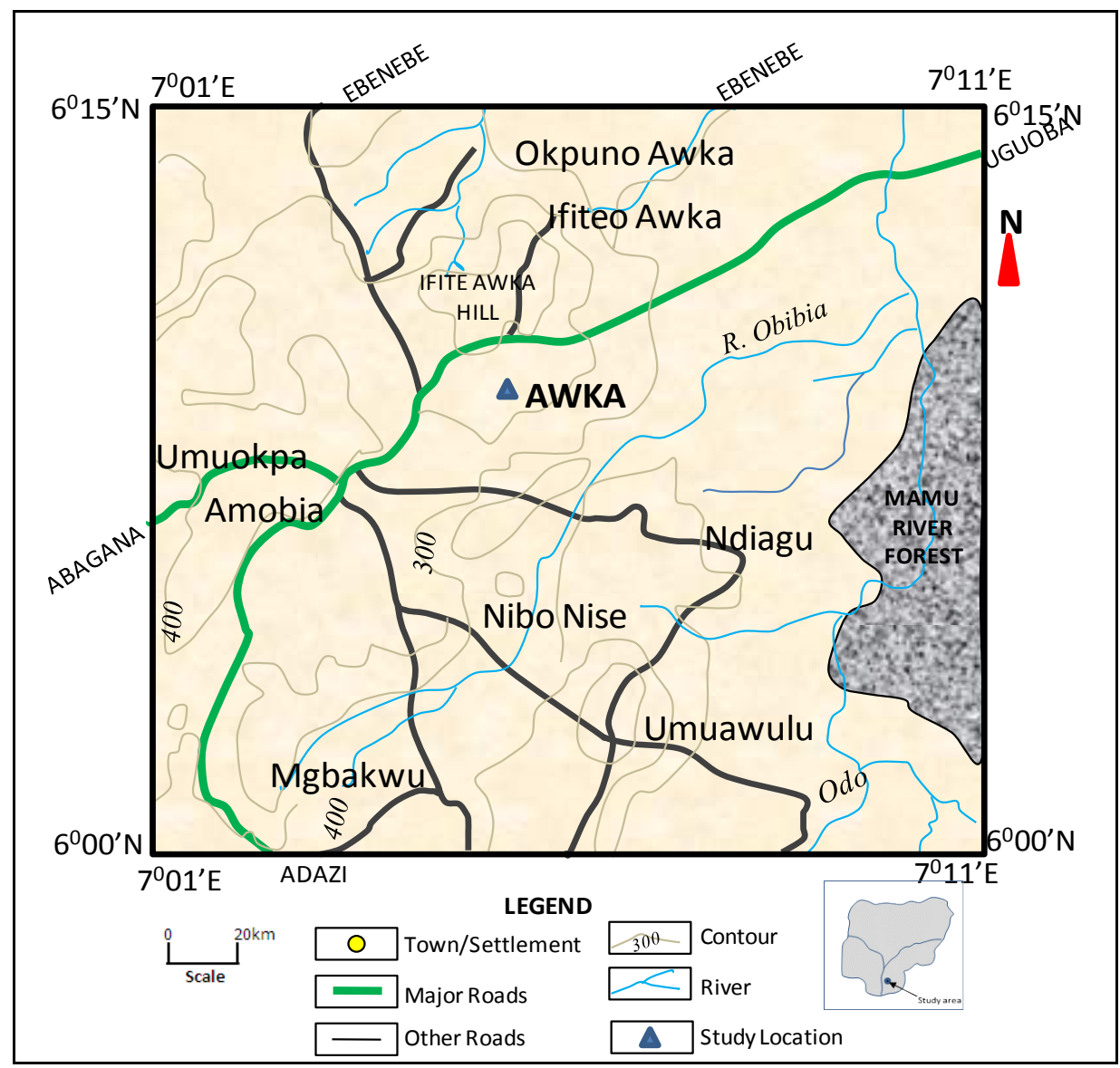

Figure 1. Topographical map of the study area 


\section{Macrothink}

Environmental Management and Sustainable Development

ISSN 2164-7682 2017, Vol. 6, No. 1

Geologically, Awka area is underlain by the Ameki (Eocene) Formation and Imo Shale Group (Paleocene) Figure (2). The Ameki Group consists of Nanka Sandstone, Nsugbe Formation and Ameki Formation (Nwajide, 1979). The Ameki Formation outcrops in the study area and consists predominantly of alternating shale, sandy shale, clay, sandstone and fine grained fossiliferous sandstone with thin bands of limestone (Reyment, 1965; Arua 1986). The age of the formation has been considered to be either early Eocene (Reyment, 1965) or early-mid Eocene (Bergeren, 1960; Adegoke 1969). The depositional environment has been interpreted as estuary and open marine based on faunal content. Nwajide (1979) and Arua (1986) suggested environments that ranged from nearshore to intertidal and subtidal zones of the shelf, whereas Fayose and Ola (1990) suggested that the sediments were deposited in shallow marine waters of 10 and $100 \mathrm{~m}$ paleobathymetry.

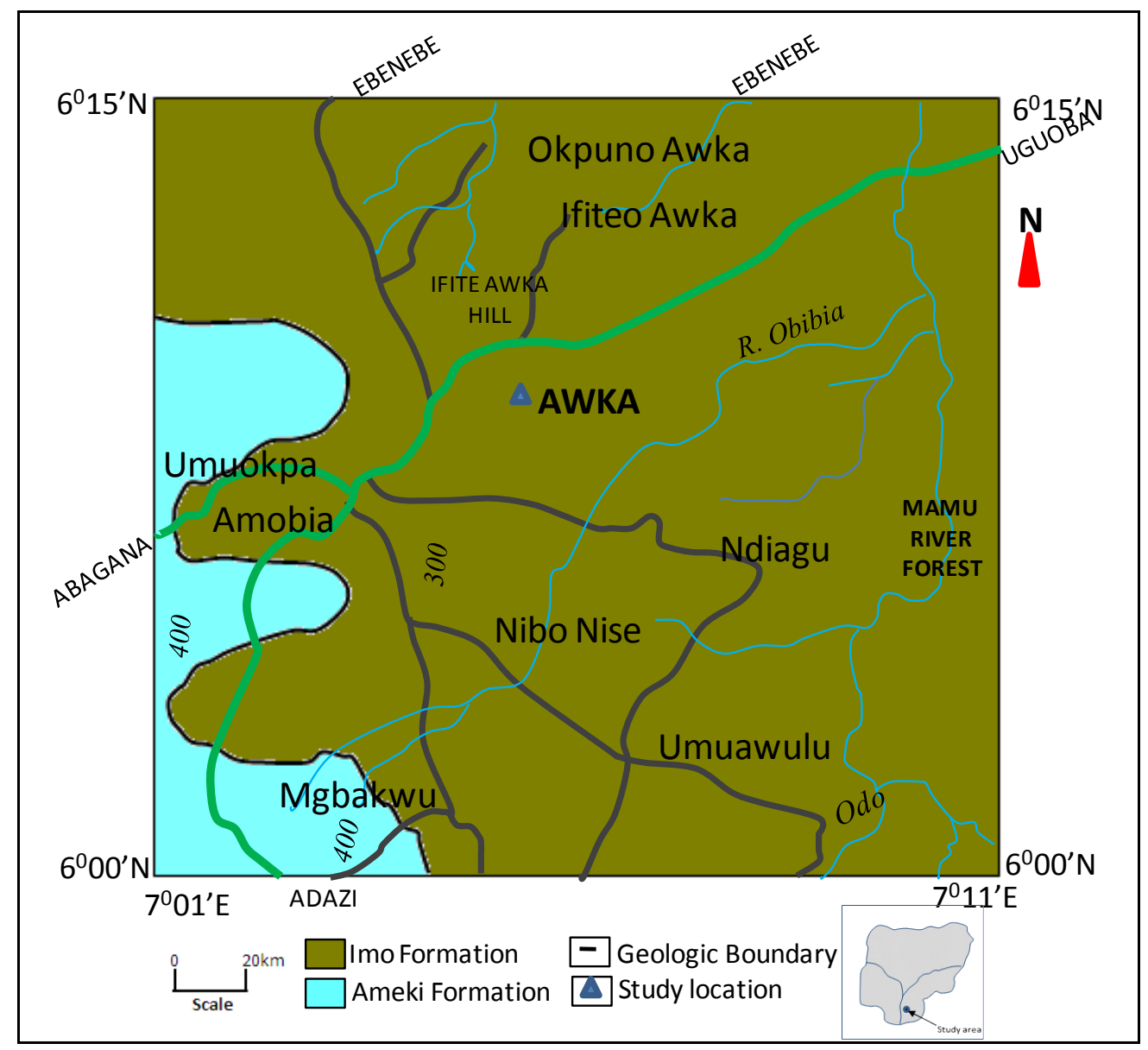

Figure 2. Geological map of the study area

The Imo Formation consists of blue-grey clays and shales with bands of calcareous sandstone, marl and limestone (Reyment, 1965). Imo Formation is the outcropping lithofacies equivalent of Akata Formation in the subsurface Niger Delta (Short and Stauble 1967, Avbovbo, 1978). The stratigraphic sequence of the study area is shown in Table 1. 


\section{Macrothink}

Table 1. Stratigraphic sequence of the study area (Reyment, 1965)

\begin{tabular}{|l|l|l|l|}
\hline AGE & Period & FORMATION & CHARACTERISTICS \\
\hline $33.9-$ & Eocene & $\begin{array}{l}\text { Ameki /Nanka, } \\
\text { Formation/ Nugbe } \\
\text { Sst (Ameki Group) }\end{array}$ & $\begin{array}{l}\text { Sandstone- grey to green argillaceous sandstone, shales and } \\
\text { thin limestone bands. Coarse-grained sandstone with abundant } \\
\text { intercalations of calcareous shale and thin shaly limestone }\end{array}$ \\
\cline { 2 - 5 } & & & Bluish to greyish clay, well laminated clayey shales \\
\hline
\end{tabular}

\section{Climate and Physiography}

The study area lies within the humid tropical rainforest belt of Nigeria. It is bounded by fresh water swamp to the south and the guinea savannah grassland to the north. The major climate variables are Rainy and Dry seasons brought about by the two predominant winds in the area. These winds are the south western monsoon wind from the Atlantic Ocean and the north eastern dry winds from across the Sahara desert, respectively. The rains last between April and October, followed by five months of dryness (November to March), (Illoeje, 1980). A short spell, the Harmattan period, is particularly dry and dusty, and commences in the study area by December. It is characterized by a grey haze that limits visibility and blocks sun rays.

Forest vegetation in the study area have been lost due to farming and other anthropogenic activities. Fringing forest however exit around rivers, streams and other wetlands that dot the area.

\section{Materials and Method}

Six water samples were collected from boreholes located at different points in the study area. The water samples were stored in pre-treated $50 \mathrm{cl}$ plastic containers and taken to the laboratory for analyses. The water quality analyses followed recommended standard methods. The parameters analysed were colour, $\mathrm{pH}$, conductivity, total dissolved solids (TDS) and Total suspended solids (TSS). Others are Nitrate $\left(\mathrm{NO}_{3}{ }^{-}\right)$, Chloride $\left(\mathrm{Cl}^{-}\right)$, Sulphate $\left(\mathrm{SO}_{4}{ }^{2-}\right)$, Phosphate $\left(\mathrm{PO}_{4}{ }^{3}\right)$, Copper $\left(\mathrm{Cu}^{2+}\right)$, Lead $\left(\mathrm{Pb}^{2+}\right)$, Cadmium $\left(\mathrm{Cd}^{2+}\right)$, Zinc $\left(\mathrm{Zn}^{2+}\right)$, Iron $\left(\mathrm{Fe}^{2+}\right)$, total hardness (calcium hardness and magnesium hardness) and alkalinity.

The analyses in the laboratory were carried out using atomic absorption spectroscopy for $\mathrm{Ca}^{2+}, \mathrm{Na}^{+}, \mathrm{Mg}^{2+}$ and $\mathrm{Cl}^{-}$, while $\mathrm{Pb}^{2+}, \mathrm{Cd}$, and $\mathrm{Cu}$ were analysed with the aid of spectrometer. $\mathrm{K}^{+}$was determined using the flame photometer. $\mathrm{pH}$ was measured with standard $\mathrm{pH}$ meter, while the concentration of the total iron $\left(\mathrm{Fe}^{2+}\right)$ was determined calorimetrically using Spekker absorption meter. Total dissolved solids (TDS) were determined using glass fibre. Turbimeter was used to assess turbidity. Physical parameters like $\mathrm{pH}$ and dissolved oxygen were measured in situ in the field with the appropriate standard meters. Anions like $\mathrm{HCO}_{3}$ were estimated by titrimetric method. All details of analytical procedures used, have been reported in Freeze and Cherry (1979).

The concentrations of cations like $\mathrm{Ca}^{2+}, \mathrm{Mg}^{2+}$ and $\mathrm{Na}^{+}$in milliequivalent per litre were later used to obtain sodium absorption ratio (SAR). 


\section{Results and Discussion}

The results of the analyses Table 2, show the concentrations of the physicochemical constituents of the underground water borehole samples in Awka area with the corresponding WHO, 2006 standard for safe drinking water.

Table 2. Physiochemical Data of measured parameters of Awka Water boreholes

\begin{tabular}{|l|c|c|c|c|c|c|c|c|}
\hline \multicolumn{1}{|c|}{ PARAMETERS } & BH1 & BH2 & BH3 & BH4 & BH5 & BH6 & AVER & WHO, 2006 \\
\hline pH $\left(31^{\circ} \mathrm{C}\right)$ & 6.91 & 6.84 & 7.01 & 6.89 & 6.90 & 6.93 & 6.97 & $6-8.5$ \\
\hline Sodium $(\mathrm{Na}+)$ & 0.86 & 0.45 & 1.23 & 2.82 & 0.89 & 1.54 & 1.30 & 50 \\
\hline Potassium $(\mathrm{K}+)$ & 1.46 & 3.11 & 4.44 & 4.01 & 4.84 & 2.53 & 3.40 & 10 \\
\hline Calcium $\left(\mathrm{Ca}^{2+}\right)$ & 4.86 & 3.37 & 3.46 & 8.03 & 9.86 & 4.04 & 5.60 & 200 \\
\hline Magnesium $\left(\mathrm{Mg}^{2+}\right)$ & 2.53 & 2.86 & 2.43 & 3.99 & 6.47 & 3.00 & 3.55 & 150 \\
\hline Total Hardness & 7.39 & 6.23 & 5.89 & 12.02 & 16.33 & 7.04 & 9.15 & 500 \\
\hline TDS & 5.16 & 7.04 & 12.45 & 8.01 & 19.61 & 9.02 & 10.22 & 500 \\
\hline Chloride $\left(\mathrm{CL}^{-}\right)$ & 4.01 & 4.15 & 6.71 & 8.23 & 4.14 & 3.48 & 5.12 & 250 \\
\hline Sulphate $\left(\mathrm{SO}_{4}^{2-}\right)$ & 3.16 & 1.41 & 2.39 & 5.64 & 2.45 & 2.13 & 2.86 & 400 \\
\hline Nitrates $\left(\mathrm{NO}_{3}^{-}\right)$ & 2.43 & 2.33 & 1.93 & 2.66 & 3.33 & 2.18 & 2.48 & 50 \\
\hline Phosphates & 6.01 & 4.30 & 6.70 & 5.43 & 5.05 & 3.40 & 5.15 & 1.0 \\
\hline Iron $\left(\mathrm{Fe}^{2+}\right)$ & 0.82 & 0.019 & 0.220 & .060 & 0.473 & .090 & 0.157 & 0.3 \\
\hline Lead $\left(\mathrm{Pb}^{2+}\right)$ & ND & ND & ND & ND & 0.0013 & ND & ND & 0.05 \\
\hline Copper $\left(\mathrm{Cu}^{2+}\right)$ & 0.0010 & ND & ND & .0030 & 0.0110 & ND & 0.003 & 1.00 \\
\hline Cadmium $\left(\mathrm{Cd}^{2+}\right)$ & ND & ND & ND & ND & 0.0012 & ND & ND & 0.05 \\
\hline Zinc $\left(\mathrm{Zn}^{2+}\right)$ & 1.0030 & 0.0940 & 0.0031 & 0.0213 & 1.0460 & 0.0011 & 0.36 & 5.00 \\
\hline Manganese $\left(\mathrm{Mn}^{2+}\right)$ & ND & ND & ND & ND & ND & ND & ND & 0.02 \\
\hline Bicarbonate $\left(\mathrm{HCO}_{3}^{-}\right)$ & 6.03 & 4.92 & 5.11 & 5.28 & 9.67 & 4.34 & 5.90 & 380 \\
\hline Conductivity & 5.14 & 5.73 & 6.62 & 6.98 & 7.30 & 5.11 & 6.15 & 500 \\
\hline TSS & 2.79 & 1.99 & 3.01 & 2.82 & 3.31 & 2.55 & 2.75 & 1000 \\
\hline Turbidity & 6.14 & 8.38 & 6.66 & 8.01 & 12.37 & 6.06 & 7.94 & 000 \\
\hline
\end{tabular}

From Table 2, all the parameters are in $\mathrm{Mg} / \mathrm{l}$ except for conductivity $(\mathrm{Ms} / \mathrm{cm})$, turbidity and $\mathrm{pH}$.

$\mathrm{ND}=$ Not detected

Using the world Health Organization standard for safe drinking water (WHO, 2006), it was observed that a few of the inorganic chemical elements are in excess of the recommended concentrations for some of the borehole waters in the study area. For example phosphate with concentrations ranging between 3.40 to $6.70 \mathrm{mg} / \mathrm{l}$, are well above the standard of $1.00 \mathrm{mg} / \mathrm{l}$ recommended by WHO, 2006 Figure (3); Table 3. The concentrations of the other anions and cations like bicarbonate, sulphate, nitrate, chloride, calcium, sodium, etc. are within acceptable limits prescribed by WHO, 2006, Figure (3) and Table 3. It should be pointed out that phosphate that is high in groundwater in the area is probably introduced from agricultural activities, leachates and seepages from dump sites and animal farms. Even though sulphate and nitrate concentrations are below their respective limits, their future status should be monitored because they together with phosphate are associated with fertiliser applications. 


\section{Macrothink}

Excess sulphate in water causes diarrhoea and purgatives in humans while high nitrate is dangerous to pregnant women and poses serious problems to infant less than three to six months of age, because of its ability to cause methemoglobinaemia or blue baby syndrome, in which blood losses its ability to carry sufficient oxygen.

The concentrations of total solids (TS), total dissolved solids (TDS) and total suspended solids (TSS), are well below the limits recommended for safe drinking water Figure (4) and Table 4. This result is indicative of excellent borehole construction and development.

Table 3. Values of Phosphates (PO4-3), Sulphate (SO42-), Nitrate (NO32-) and Chloride (Cl-) as well as bicarbonate (HCO3-) in the six boreholes

\begin{tabular}{|l|c|c|c|c|c|c|c|c|}
\hline Parameters & BH1 & BH2 & BH3 & BH4 & BH5 & BH6 & WHO 2006 & REMARKS \\
\hline Phosphates & 6.01 & 4.30 & 6.70 & 5.43 & 5.05 & 3.40 & 1.00 & Very high \\
\hline Sulphates & 3.16 & 1.41 & 2.39 & 5.64 & 2.45 & 2.13 & 400 & Low \\
\hline Nitrates & 2.43 & 2.33 & 1.93 & 2.66 & 3.33 & 2.18 & 45.50 & Low \\
\hline Chloride & 4.01 & 4.15 & 6.71 & 8.23 & 4.14 & 3.48 & 250 & Low \\
\hline Bicarbonate & 6.03 & 4.94 & 5.11 & 5.28 & 9.67 & 4.34 & 380 & Low \\
\hline
\end{tabular}

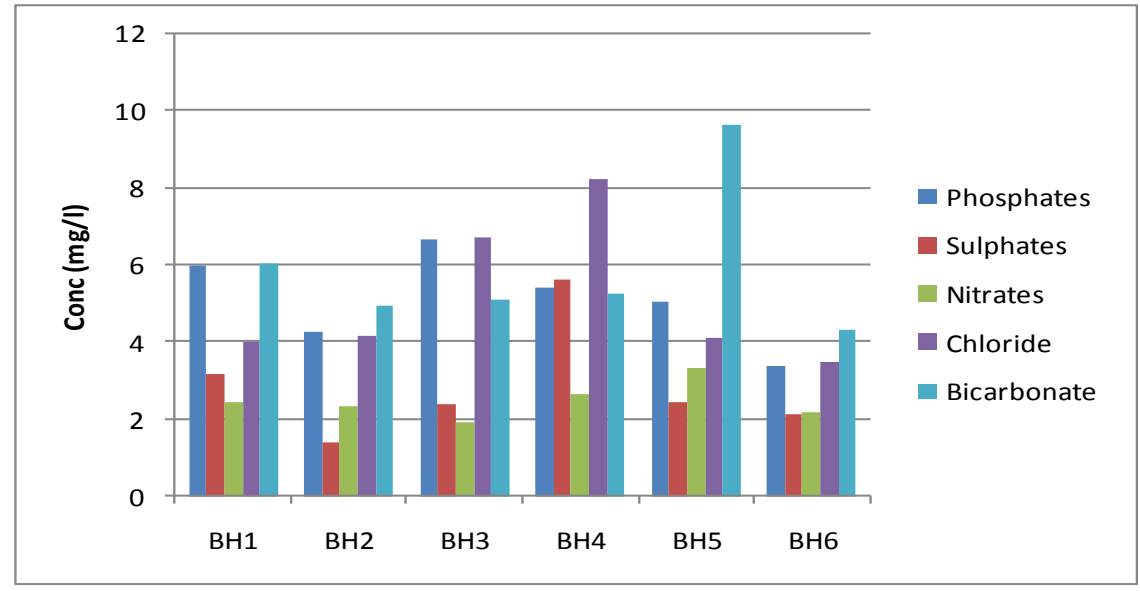

Figure (3) Major Anions in the analysed samples expressed as a bar chart

Table 4. TS, TSS and TDS of the area

\begin{tabular}{|c|c|c|c|c|c|c|c|}
\hline Parameters & BH1 & BH2 & BH3 & BH4 & BH5 & BH6 & WHO \\
\hline TS & 7.9 & 8.03 & 15.45 & 10.83 & 22.92 & 11.57 & 1000 \\
\hline TDS & 5.16 & 7.04 & 12.45 & 8.01 & 19.61 & 9.02 & 1000 \\
\hline TSS & 2.79 & 1.97 & 3.01 & 2.28 & 3.31 & 2.55 & 1000 \\
\hline
\end{tabular}




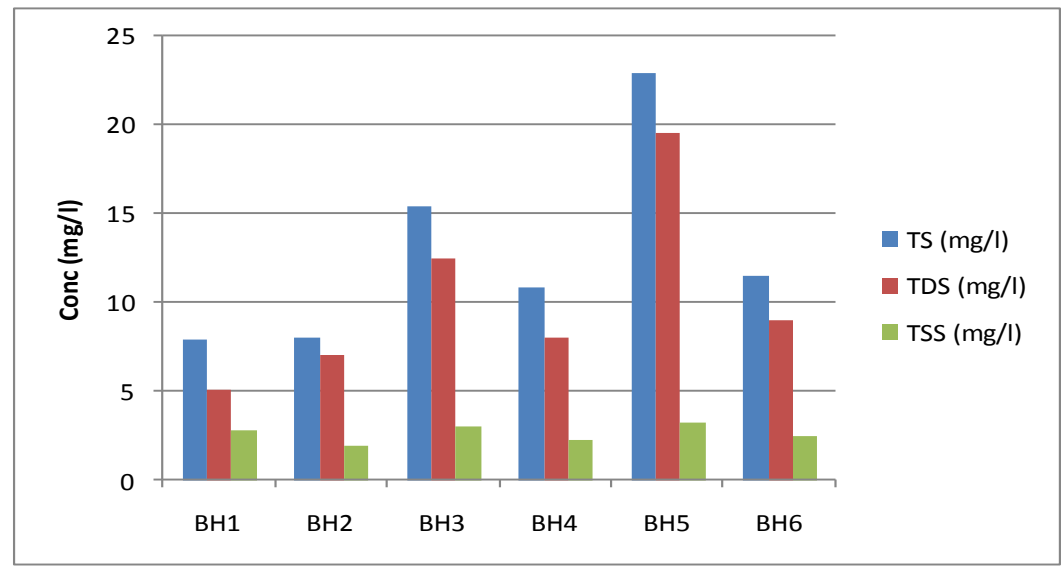

Figure 4. Representative Histogram Plots of TS, TSS, and TDS for BH6 in the study area

The $\mathrm{pH}$ of the groundwater is neutral to alkaline Figure 5; Table 5. This result shows that mean $\mathrm{pH}$ value of 6.90 for the groundwater in Awka area is potable and indicates also that the groundwater will not corrode pipes and other metal fittings (Corrodible materials).

Table 5. Values of $\mathrm{pH}$, turbidity, TSS, TDS, conductivity and total hardness

\begin{tabular}{|c|c|c|c|c|c|c|c|c|}
\hline S/n & Parameters & BH1 & BH2 & BH3 & BH4 & BH5 & BH6 & WHO 2006 \\
\hline 1 & pH & 6.91 & 6.84 & 7.01 & 6.89 & 6.90 & 6.93 & $6-8.8$ \\
\hline 2 & Turbidity & 6.14 & 8.38 & 6.66 & 8.01 & 12.37 & 6.06 & 100 \\
\hline 3 & TSS & 2.79 & 1.97 & 3.01 & 2.28 & 3.31 & 2.55 & 1000 \\
\hline 4 & TDS & 5.16 & 7.04 & 12.45 & 8.01 & 19.61 & 9.02 & 1000 \\
\hline 5 & Conductivity & 5.41 & 5.73 & 6.62 & 6.98 & 7.30 & 5.11 & 50 \\
\hline 6 & Total hardness & 7.39 & 6.23 & 5.84 & 12.02 & 16.33 & 7.04 & 500 \\
\hline
\end{tabular}

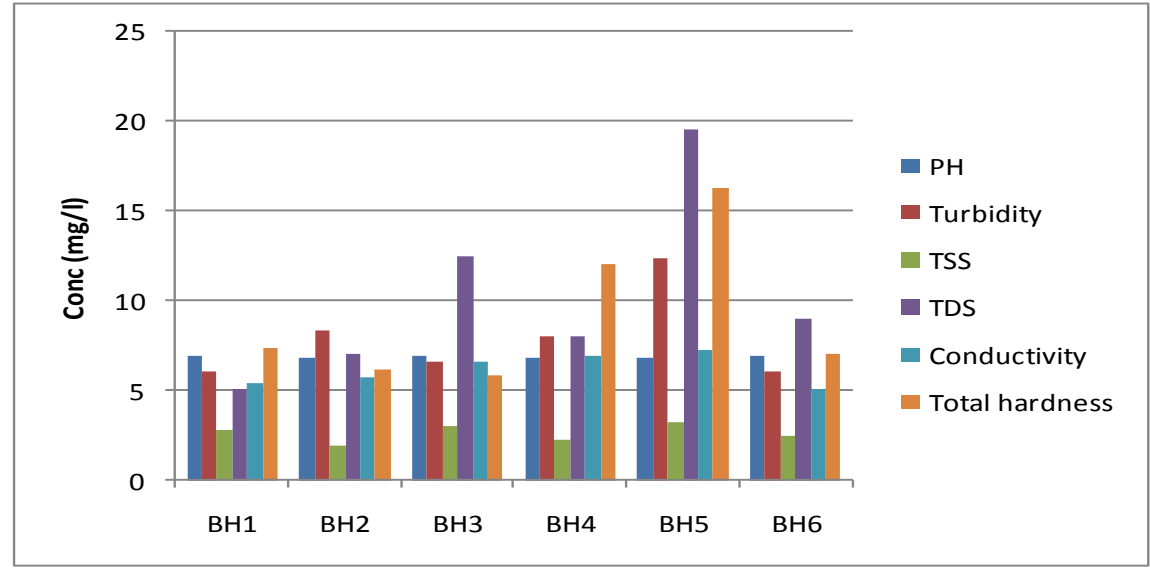

Figure 5. The histogram plots of $\mathrm{pH}$, turbidity, TSS, TDS, conductivity and total hardness

The measured heavy metal contents of iron, copper, cadmium, zinc and lead are displayed in 


\section{Macrothink}

Table 6. The results showed that while zinc and copper were not detected in most of the groundwater in the area, iron and lead are in excess in some of the boreholes according to the scale of WHO, 2006. It also showed that the high iron content for example is localised (in $\mathrm{BH} 1, \mathrm{BH} 3$ and $\mathrm{BH} 4)$, which may be indicative of point sources, like an auto village or the direct result of the geology of the affected areas. High concentration of iron in water is not generally poisonous but causes brownish precipitates due to oxidation of iron in form of $\mathrm{Fe}_{2}$ $(\mathrm{OH})_{3}$ which does not present an aesthetic appeal to toilets and other household items. Lead is toxic (Short and Stauble 1967) as it forms lead oxide $\left(\mathrm{PbO}_{2}\right)$ when mixed with blood.

Table 6. Results of heavy metals analysis

\begin{tabular}{|c|l|c|c|c|c|c|c|c|c|}
\hline No. & Parameters & BH1 & BH2 & BH3 & BH4 & BH5 & BH6 & WHO 2006 & REMARK \\
\hline 1 & Iron & 0.82 & 0.019 & 0.220 & 0.060 & 0.473 & 0.090 & 0.3 & High \\
\hline 2 & Copper & ND & ND & ND & ND & 0.0013 & ND & 1.00 & - \\
\hline 3 & Cadmium & 0.0010 & 0.002 & ND & 0.003 & 0.0110 & ND & 0.05 & Low \\
\hline 4 & Zinc & ND & ND & ND & ND & 0.0012 & ND & 5.00 & - \\
\hline 5 & Lead & 1.0030 & 0.0940 & 0.0031 & 0.0213 & 1.0460 & 0.0011 & 0.05 & High \\
\hline
\end{tabular}

SAR VERIFICATION: Sodium absorption ratio (SAR) according to Richard, 1985 is an important parameter for determining the suitability of water for irrigation. It is a measure of alkali/sodium hazards to crops. Sodium absorbed clay minerals displace $\mathrm{Mg}^{2+}$ and $\mathrm{Ca}^{2+}$ ions. This process reduces the permeability of soils resulting to poor internal drainage (Collins and Jenkins, 1960). Richard (1985) classified water standard for irrigation based on sodium absorption ratio Table 7 .

SAR of water in the area was obtained using equation 1 to generate SAR values, Table 8 which were compared with the Richard (1985) classified standard for irrigation. On comparism it was shown that the inorganic elements of the groundwater in the study area are excellent for irrigation purposes Table 8 .

$$
\begin{array}{r}
S A R=\quad \frac{N a+}{\sqrt{(C a 2++M g 2+)} 1 / 2}
\end{array}
$$

Where $\mathrm{Na}^{+}, \mathrm{Mg}$ and $\mathrm{Ca}^{2+}$ are the respective concentrations of sodium, magnesium and calcium in $\mathrm{Mg} / \mathrm{l}$ contained in the groundwater. 
Table 7. Water classification scheme using SAR (Richard, 1985)

\begin{tabular}{|c|c|}
\hline SAR & Water Class \\
\hline $0-10$ & Excellent \\
\hline $10-18$ & Good \\
\hline $18-28$ & Fair \\
\hline$>26$ & Poor \\
\hline
\end{tabular}

Table 8. SAR status of boreholes 1-6

\begin{tabular}{|c|c|c|c|c|c|}
\hline Sample & $\mathbf{N a}^{\mathbf{2 +}}$ & $\mathbf{C a}^{\mathbf{2 +}}$ & $\mathbf{M g}^{\mathbf{2 +}}$ & $\mathbf{S A R}$ & Remark \\
\hline BH1 & 0.86 & 4.86 & 2.53 & 0.32 & Excellent \\
\hline BH2 & 0.45 & 3.37 & 2.86 & 0.18 & Excellent \\
\hline BH3 & 1.23 & 3.46 & 2.43 & 0.51 & Excellent \\
\hline BH4 & 2.82 & 8.03 & 3.99 & 0.81 & Excellent \\
\hline BH5 & 0.89 & 9.86 & 6.47 & 0.22 & Excellent \\
\hline BH6 & 1.54 & 4.04 & 3.00 & 0.58 & Excellent \\
\hline
\end{tabular}

The average concentrations of major cations and anions were used in equation 2 to derive values, which are converted values from $\mathrm{mg} / \mathrm{l}$ to meq/l Table 9 . The converted values were plotted into the piper trilinear diagrams (Piper, 1944) in order to decipher the potability, water types and classes of the borehole waters in Awka area Figure (6).

$$
\text { Conc. }=\text { Conc. } \mathrm{Mg} / \mathrm{L} / \text { Equivalent weight }
$$

Table 9. Conversion of anions and cations from $\mathrm{mg} / \mathrm{l}$ to meq/l

\begin{tabular}{|c|c|c|c|c|c|c|}
\hline $\begin{array}{c}\text { Measured Parameters } \\
\text { CATION }\end{array}$ & Conc. Mg/l & Atomic weight & Charge & Equiv. Wt & Conc. $\mathrm{Mg} / \mathrm{L}$ & \% of component \\
\hline $\mathrm{Ca}^{2+}$ & 5.60 & 40.0 & +2 & 20.04 & 0.28 & 38.89 \\
\hline $\mathrm{Mg}^{2+}$ & 3.55 & 24.31 & +2 & 12.16 & 0.29 & 40.28 \\
\hline $\mathrm{Na}^{+}$ & 1.30 & 22.98 & +1 & 22.98 & 0.06 & 8.33 \\
\hline $\mathrm{K}^{+}$ & 3.40 & 39.10 & +1 & 39.10 & 0.009 & 12.5 \\
\hline Total & & & & & $\mathbf{0 . 7 2}$ & $\mathbf{1 0 0}$ \\
\hline $\mathrm{ANION}^{\mathrm{HCO}_{3-}}$ & 5.90 & 61.02 & -1 & 61.02 & 0.10 & 33.33 \\
\hline $\mathrm{SO}_{4}^{2-}$ & 2.86 & 96.06 & -2 & 48.03 & 0.06 & 20.0 \\
\hline $\mathrm{Cl}^{-}$ & 5.12 & 35.45 & -1 & 35.45 & 0.14 & 46.7 \\
\hline Total & & & & & $\mathbf{0 . 3}$ & $\mathbf{1 0 0}$ \\
\hline
\end{tabular}




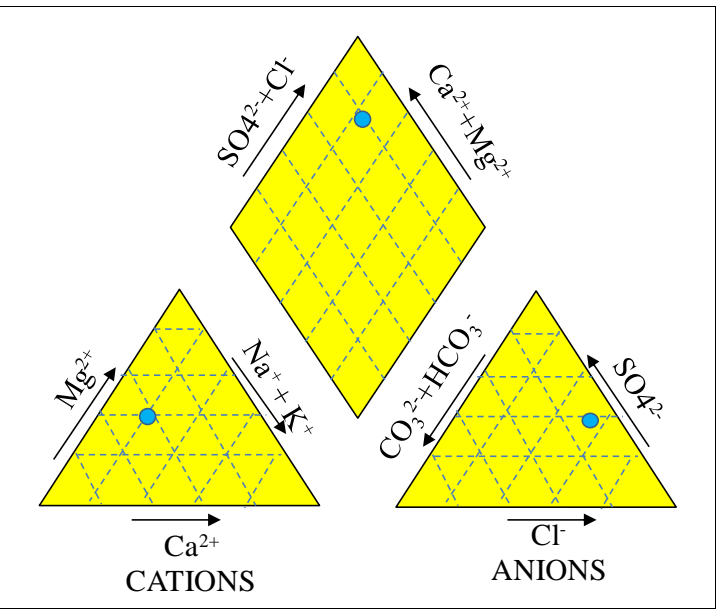

Figure 6. Piper Trilinear diagram using average compositions of major cations and anions in the study area

The piper trilinear diagram of Figure (6) indicates that the water is potable based on its position at the diamond end of the plot.

The spatial distribution of anions and cations in the study area were also used to compute the water types of the groundwater system at various locations in the study area Table 10 and Figure 7. The spatial distribution shows that the dominant water type is tending toward magnesium chloride.

Table 10. The spatial distributions of the anions and cations of the groundwater in Awka area

\begin{tabular}{|c|c|c|c|c|c|c|}
\hline Parameters & $\begin{array}{c}\text { Conc. } \\
\mathrm{Mg} / \mathrm{l}\end{array}$ & $\begin{array}{c}\text { Atomic Weight } \\
\mathrm{Mg} / \mathrm{l} \\
\end{array}$ & charge & $\begin{array}{c}\text { Equivalent Weight } \\
\mathrm{Mg} / \mathrm{l} \\
\end{array}$ & $\begin{array}{l}\mathrm{Conc} \\
\mathrm{Mg} / \mathrm{l}\end{array}$ & $\begin{array}{c}\text { \% of component } \\
\mathrm{Mg} / \mathrm{l}\end{array}$ \\
\hline \multicolumn{7}{|c|}{ BH1 CATION } \\
\hline $\mathrm{Ca}^{2+}$ & 4.86 & 40.0 & +2 & 20.04 & 0.24 & 45.28 \\
\hline $\mathrm{Mg}^{2+}$ & 2.53 & 24.31 & +2 & 12.16 & 0.21 & 39.62 \\
\hline $\mathrm{Na}^{+}$ & 0.86 & 22.98 & +1 & 22.98 & 0.04 & 7.55 \\
\hline $\mathrm{K}^{+}$ & 1.46 & 39.10 & +1 & 31.10 & 0.04 & 7.55 \\
\hline Total & & & & & 0.53 & 100 \\
\hline \multicolumn{7}{|c|}{ BH1 ANION } \\
\hline $\mathrm{HCO}_{3-}$ & 6.03 & 61.02 & -1 & 61.02 & 0.10 & 35.71 \\
\hline $\mathrm{SO}_{4}{ }^{2-}$ & 3.16 & 96.06 & -2 & 48.03 & 0.07 & 25 \\
\hline $\mathrm{Cl}^{-}$ & 4.01 & 35.45 & -1 & 35.45 & 0.11 & 39.29 \\
\hline Total & & & & & 0.28 & 100 \\
\hline \multicolumn{7}{|c|}{ BH2 CATION } \\
\hline $\mathrm{Ca}^{2+}$ & 3.37 & 40.0 & +2 & 20.0 & 0.24 & 33.33 \\
\hline $\mathrm{Mg}^{2+}$ & 2.86 & 24.31 & +2 & 12.16 & 0.02 & 47.061 \\
\hline $\mathrm{Na}^{+}$ & 0.45 & 22.98 & +1 & 22.98 & 0.08 & 3.921 \\
\hline $\mathrm{K}^{+}$ & 3.11 & 39.10 & +1 & 39.10 & .51 & 15.69 \\
\hline Total & & & & & & 99.96 \\
\hline
\end{tabular}




\begin{tabular}{|c|c|c|c|c|c|c|}
\hline \multicolumn{7}{|c|}{ BH2 ANION } \\
\hline $\mathrm{HCO}_{3-}$ & 4.92 & 61.02 & -1 & 61.02 & .08 & 34.78 \\
\hline $\mathrm{SO}_{4}{ }^{2-}$ & 1.41 & 96.06 & -2 & 48.03 & .03 & 13.04 \\
\hline $\mathrm{Cl}^{-}$ & 4.15 & 35.45 & -1 & 35.45 & .12 & 52.17 \\
\hline Total & & & & & .23 & 99.99 \\
\hline \multicolumn{7}{|c|}{ BH3 CATION } \\
\hline $\mathrm{Ca}^{2+}$ & 3.46 & 40.0 & +2 & 20.04 & .17 & 32.08 \\
\hline $\mathrm{Mg}^{2+}$ & 2.43 & 24.31 & +2 & 12.16 & .20 & 37.73 \\
\hline $\mathrm{Na}^{+}$ & 1.23 & 22.98 & +1 & 22.98 & .05 & 9.43 \\
\hline $\mathrm{K}^{+}$ & 4.44 & 39.10 & +1 & 39.10 & .11 & 20.75 \\
\hline Total & & & & & .53 & 99.99 \\
\hline \multicolumn{7}{|c|}{ BH3 ANION } \\
\hline $\mathrm{HCO}_{3-}$ & 5.11 & 61.02 & -1 & 61.02 & .08 & 25 \\
\hline $\mathrm{SO}_{4}{ }^{2-}$ & 2.39 & 96.06 & -2 & 48.03 & .05 & 15.63 \\
\hline $\mathrm{Cl}^{-}$ & 6.71 & 35.45 & -1 & 35.45 & .19 & 59.38 \\
\hline Total & & & & & .32 & 100 \\
\hline \multicolumn{7}{|c|}{ BH4 CATION } \\
\hline $\mathrm{Ca}^{2+}$ & 8.03 & 40.01 & +2 & 20.04 & .40 & 56.33 \\
\hline $\mathrm{Mg}^{2+}$ & 3.99 & 24.31 & +2 & 12.16 & .09 & 12.68 \\
\hline $\mathrm{Na}^{+}$ & 2.82 & 22.98 & +1 & 22.98 & 0.12 & 16.90 \\
\hline $\mathrm{K}^{+}$ & 4.01 & 39.10 & +1 & 39.10 & 0.10 & 14.08 \\
\hline Total & & & & & 0.71 & 99.9 \\
\hline \multicolumn{7}{|c|}{ BH4 ANION } \\
\hline $\mathrm{HCO}_{3-}$ & 5.28 & 61.02 & -1 & 61.02 & .09 & 22.45 \\
\hline $\mathrm{SO}_{4}{ }^{2-}$ & 5.64 & 96.06 & -2 & 48.03 & .12 & 27.27 \\
\hline $\mathrm{Cl}^{-}$ & 8.23 & 35.45 & -1 & 35.45 & .23 & 52.27 \\
\hline Total & & & & & 0.44 & 99.99 \\
\hline \multicolumn{7}{|c|}{ BH5 CATION } \\
\hline $\mathrm{Ca}^{2+}$ & 9.86 & 40.0 & +2 & 20.04 & .45 & 39.47 \\
\hline $\mathrm{Mg}^{2+}$ & 6.47 & 24.31 & +2 & 12.96 & .53 & 46.49 \\
\hline $\mathrm{Na}^{+}$ & 0.89 & 22.98 & +1 & 22.98 & .04 & 3.51 \\
\hline $\mathrm{K}^{+}$ & 4.84 & 39.10 & +1 & 39.10 & .12 & 10.53 \\
\hline Total & & & & & 1.14 & 100 \\
\hline \multicolumn{7}{|c|}{ BH5 ANION } \\
\hline $\mathrm{HCO}_{3-}$ & 9.67 & 61.02 & -1 & 61.02 & 0.16 & 48.48 \\
\hline $\mathrm{SO}_{4}{ }^{2-}$ & 2.45 & 96.06 & -2 & 48.03 & 0.05 & 15.15 \\
\hline $\mathrm{Cl}^{-}$ & 4.14 & 35.45 & -1 & 35.45 & 0.12 & 36.36 \\
\hline Total & & & & & 0.33 & 99.99 \\
\hline \multicolumn{7}{|c|}{ BH6 CATION } \\
\hline $\mathrm{Ca}^{2+}$ & 4.04 & 40 & +2 & 20.04 & 0.20 & 34.48 \\
\hline $\mathrm{Mg}^{2+}$ & 3.00 & 24.31 & +2 & 12.16 & 0.25 & 43.10 \\
\hline $\mathrm{Na}^{+}$ & 1.54 & 22.98 & +1 & 22.98 & 0.07 & 12.07 \\
\hline
\end{tabular}




\begin{tabular}{|l|c|c|c|c|c|c|}
\hline $\mathrm{K}^{+}$ & 2.53 & 39.10 & +1 & 39.10 & 0.06 & 10.34 \\
\hline Total & \multicolumn{7}{|l|}{} & & 0.58 & 99.99 \\
\hline BH6 ANION & \multicolumn{7}{|l|}{} \\
\hline $\mathrm{HCO}_{3-}$ & 4.34 & 61.02 & -1 & 61.02 & .07 & 22.58 \\
\hline $\mathrm{SO}_{4}^{2-}$ & 2.13 & 96.06 & -2 & 48.03 & .04 & 12.90 \\
\hline $\mathrm{Cl}^{-}$ & 3.48 & 35.45 & -1 & 35.45 & .20 & 64.52 \\
\hline Total & & & & & & \\
\hline
\end{tabular}

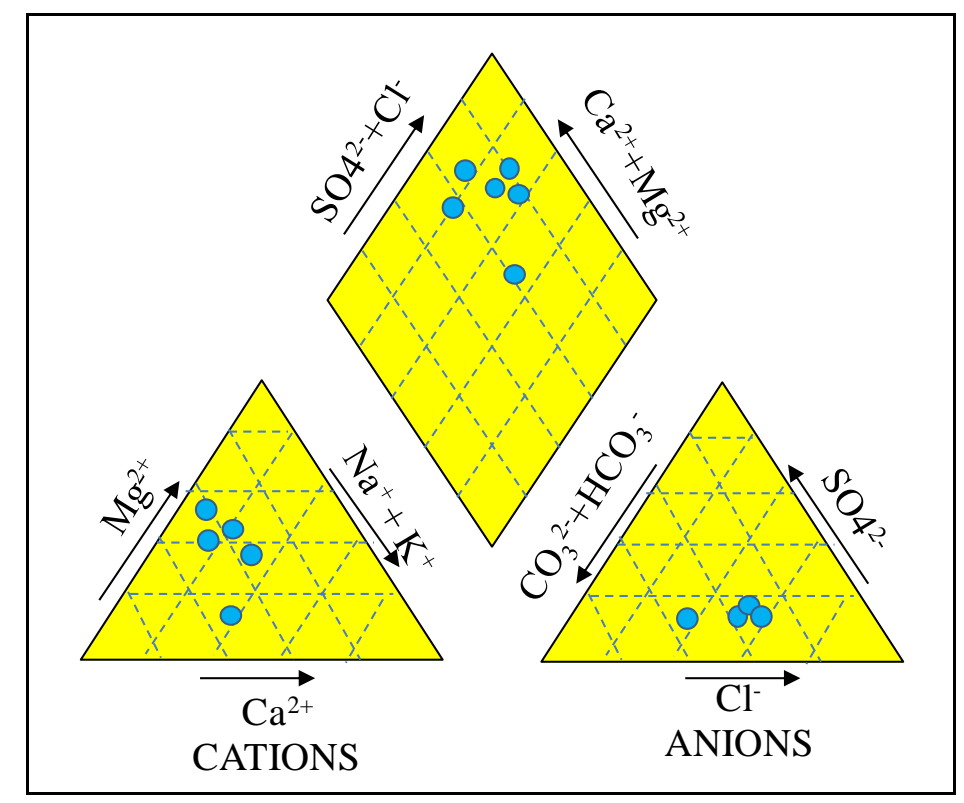

Figure 7. Spatial Distribution of cation and anions in Piper Trilinear

It is also possible to examine the extent of pollution of the groundwater based on the application of Hortons scales (1995). Hortons scale stipulates the scale of rating of pollution extent Figure 8. If the value of pollution falls at zero, it is of critical value. If it plots to the right of zero value (positive side), the water is polluted in that order. If it plots to the negative side, the water is not polluted in that order.

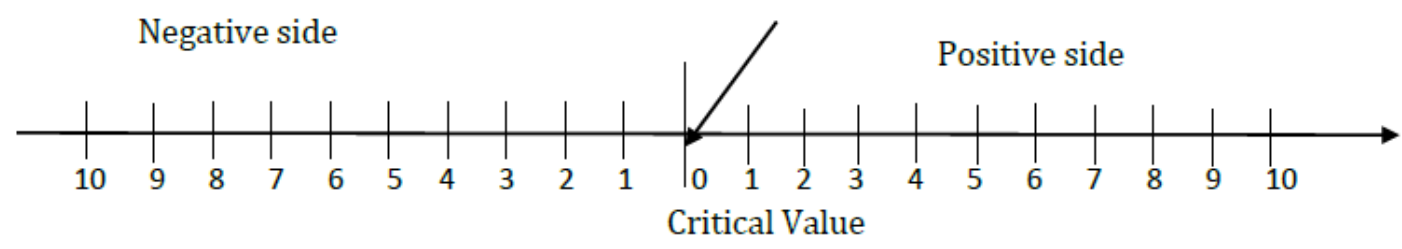

Figure 8. Horton index scale (Horton, 1995)

The computation of Horton Index number is shown in Table 11. 
Table 11. Computation of reference number of Horton (1995)

\begin{tabular}{|l|l|l|l|l|}
\hline S/N & PARAMETERS & $\begin{array}{l}\text { AVERAGE VALUE } \\
\text { IN SAMPLE }\end{array}$ & $\begin{array}{l}\text { WHO STANDARD } \\
\mathbf{2 0 0 6}\end{array}$ & $\begin{array}{l}\text { MEAN } \\
\text { AI/WIJ }\end{array}$ \\
\hline 1 & $\mathrm{pH}\left({\left.\text { at } 31^{\circ} \mathrm{C}\right)}\right)$ & 6.91 & 6.85 & 1.15 \\
\hline 2 & Potassium & 3.40 & 10 & 0.34 \\
\hline 3 & Sodium & 1.30 & 50 & 0.026 \\
\hline 4 & Calcium & 5.60 & 200 & 0.28 \\
\hline 5 & Magnesium & 3.55 & 150 & 0.024 \\
\hline 6 & Total Hardness & 9.15 & 500 & 0.018 \\
\hline 7 & Total Dissolved & 10.22 & 500 & 0.020 \\
\hline 8 & Solid (TDS) & & & \\
\hline 9 & Chloride & 5.12 & 250 & 0.020 \\
\hline 10 & Nitphate & 2.86 & 400 & .007 \\
\hline 11 & Iron & 2.48 & 50 & 0.05 \\
\hline 11 & Lead & 0.16 & 0.3 & 0.53 \\
\hline 12 & Copper & ND & - & - \\
\hline 13 & Cadmium & ND & - & - \\
\hline 14 & Zinc & 0.36 & - & - \\
\hline 15 & Manganese & ND & 5 & 0.072 \\
\hline 16 & Bicarbonate $\left(\mathrm{HCO}_{3}^{-}\right)$ & 5.90 & - & .02 \\
\hline 17 & Conductivity & 6.15 & 380 & .01 \\
\hline 18 & TSS & 2.75 & 500 & \\
\hline 19 & Turbidity & 9.94 & 1000 & \\
\hline & & & & \\
\hline
\end{tabular}

Pollution index was calculated from the relation in equation 3 :

$$
\text { Piji }=\frac{\sqrt{\left(\frac{M A X A i}{W i j}\right) 2+\left(\frac{M e a n A i}{W i j}\right) 2}}{2}
$$

Where Piji is pollution index,

$\mathrm{Ai}=$ Average value of sample analysed,

Wij is WHO Standard.

From equation 3:

$$
\text { Piji }=\frac{\sqrt{\left(1.15^{2}\right)+\left(0.0135^{2}\right)}}{2}=1.13
$$

Therefore, pollution index Piji $=1.13$

From the Hortons scale of Figure (8), the water is slightly polluted. The pollution is probably 
due to the fact that the groundwater is heavily polluted by phosphate and in some cases, iron. Phosphate is high probably due to the fact that the surrounding villages use excess phosphate fertilizer in agriculture. Animal defecation may also be a factor.

\section{Conclusion}

Iron content in the area is high (WHO, 2016). High iron may be due to the effect of industrial activities relating to the release of iron compounds. The composition of some heavy metals like lead is on the increase due probably to effluent from battery industries. High concentrations of Chloride in groundwater in the study area, though not in excess, may be due to wastes from nearby markets and septic tank leakages. High concentration of Phosphate can also be traced to leachates from waste disposals. Again sources of phosphates may be runoff from agricultural sites using phosphate fertilizers, poor management of sewage and /or due to decayed plant tissues, since phosphates are tied up in plant tissues. The area might have been used as cemetery in the past as phosphates are present in fossilized bones or animal droppings, especially, cattle reared by Fulani nomads. It may also be that apatite is somewhere in the subsurface rock. As potassium is found in aluminates $\mathrm{KAL}_{3}\left(\mathrm{SO}_{4}\right)^{2}(\mathrm{OH})_{6}$, the phosphate may have originated also from the laterite of Ameki Formation. Lead could also be due to sawmills, woodworks, auto repair workshops and can affect red blood cell chemistry in humans (Franson, 1995). Finally, the water tilted to magnesium chloride water which is good for irrigation and other household activities. Periodic monitoring of the groundwater system in the area is recommended as a management strategy.

\section{Acknowledgement}

The authors acknowledge the help of Mano Consulting Water Drilling Geologist who helped the researchers in the interpretation of the groundwater quality results. Many thanks also go to lecturers in Department Geological Sciences, Nnamdi Azikiwe University (Unizik), Awka Anambra State who helped the researchers in the interpretation of heavy metal result.

\section{References}

Assez, C. R. (1984). Hydrogeochemical pollution of lake body associated with limestone terrain, 43-60.

Akpokotye, E. (1999). Principles of applied and environmental geology, 30- 55.

AWWA. (1999. American Water Works Association. Manual of American year book.

Avbovbo, A. A. (1978). Tertiary Lithostratigraphy of Niger Delta, Bull. American Association of Petroleum geology, 295-306.

Akanymyeme, O. A. (2012). Preliminary lithologic deductions, Michael Okpara University of Agriculture Abia State Nigeria using VES method. Arch. Phy Res., 3(4), 292-309.

Akpoborie N. A., Etobori, \& Odagwa, S. (2011). Aspect of the geology and groundwater conditions of Asaba, Nigeria. Appl. Sec Sources, 3(2), 557-5502

Bassey, C., \& Emmanuel Oeminue (2012). Petrogrphic and stratigraphic analysis of 
paleogene Ogwashi Asaba Formation, Anambra Basin Nigeria NAF IA C 3(7-8), 247-254.

Cherie, R., \& Eminue, O. (1978). Some new Eocene pollera of the Ogwashi Asaba Formation, Southern Nigeria Micropaleontology, 10, 285-322.

Freeze, R. A., \& Cherry, J. A. (1979). Groundwater prentice Hall Inc., New Jersey, 64-80.

Horton, E. (1995). An index number rating system for rating water quality pollution control, 34-39.

Ibe, K. M., \& Sowa, A. H. (2002). Hydrogeology of parts of Oramiriukwa River Basin South east Owerri, Imo State, Nigeria Hydrogeology Journal, 10(4), 509.

https://doi.org/10.1007/s10040-002-0207-7

Ngah, S. A., \& Allen, R. O. (2005). High BI- valent iron contaminants in groundwater of the Niger Delta: Their genesis and distribution J. Environ. Pollu. Health, 5(1), 35-47.

Onyeagocha, A. C. (1980). Petrography and depositional environment of the Benin Formation, J. min and geology, 17(2), 147-157

Oboh-Ikuenobe, P. E., Obi, C. G., \& Jeramillo, C. A. (2005). Lithofacies. Palenofacies and sequence stratigraphy of paleocene strata in southern Nigeria, J. Afr. Earth Sci. 41, 79-101. https://doi.org/10.1016/j.jafrearsci.2005.02.002

Olisa, M., Nieto, J. M., Sarmieto, A. M., Ceron, J. C., \& Canovas, C. R. (2004). Seasonal water quality variation in a River affected by acid mine drainage, the Odiel River, SW Spain Science of the total environment, 33, 267-281. https://doi.org/10.1016/j.scitotenv.2004.05.012

Ofordile, M. E. (1982). The problems of water resources management in Nigeria, Nigerian Journal of mining and geology $20^{\text {th }}$ Anniv. Educ, 19(1).

Pitt, R. L., Alor, M., \& Brown, M. (1995). Urban storm water toxic pollutants: Assessment of source and treatability. Water environment research, 67, 260-275.

https://doi.org/10.2175/106143095X131466

Reyment, R. A. (1965). Aspect of the geology of Nigeria, University of Ibadan Press Nigeria, 16-24.

Susheela, A. K. (1991). Fluorosis management programme in current science and technology, 45-60.

Simpson, A. (1954). Groundwater hydrology second edition, pp 76-145.

Uma, K. O. (1987). Appraisal of the groundwater resources of the Imo River Basin, Nigeria. Journal of Mining geology, 25(1\&2).

Whiteman, A. (1982). Nigeria, its petroleum geology, resources and potentials. 2. Graham Trotman Pub. London, 234-241. https://doi.org/10.1007/978-94-009-7361-9

World Health Organization (WHO), 2006 or 2016 guidelines for drinking water quality. Incorporating Ist and $2^{\text {nd }}$ Addlenda, 15-20. 


\section{Macrothink \\ Environmental Management and Sustainable Development \\ ISSN 2164-7682}

\section{Copyright Disclaimer}

Copyright for this article is retained by the author(s), with first publication rights granted to the journal.

This is an open-access article distributed under the terms and conditions of the Creative Commons Attribution license (http://creativecommons.org/licenses/by/3.0/). 